\title{
EDITORIAL
}

\section{El desafío de la calidad en las universidades}

\author{
The challenge of quality in universities
}

Liliana M. Pedraja-Rejas, Emilio Rodríguez-Ponce
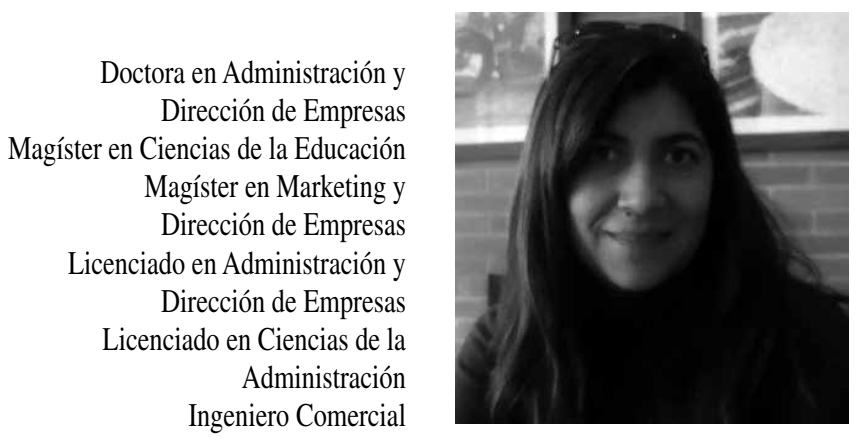

Ph.D. in Management Sciences Master of Science in Education Master of Arts in Marketing and Management Bachelor of Business Administration

Bachelor of Management

Sciences

Comercial Engineering

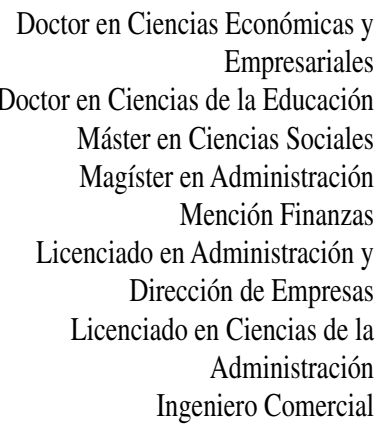

Ph.D. in Business Economics Ph.D. in Educational Sciences Master in Social Sciences Master of Science in Finance Bachelor of Business Administration Bachelor of Management Sciences Comercial Engineering
La sociedad del conocimiento es el resultado de la institucionalización y progreso de la ciencia $\mathrm{y}$, como tal, se encuentra en plena fase de construcción (Lamo de Espinosa, 2009). Ciertamente, el conocimiento ha sido desde siempre un factor de producción. No obstante, en la actualidad, la capacidad para administrar, almacenar y transmitir grandes cantidades de información a bajo precio es un elemento esencial, que caracteriza los procesos organizativos, productivos y, desde luego, las interacciones en nuestra sociedad (Neubauer, 2012).

El sector público y privado emplea comúnmente para su labor herramientas tecnológicas, incluyendo aplicaciones de redes sociales como Twitter, Facebook o Wikis (Allen e Imrie, 2012). Asimismo, se ha evolucionado desde la Web 1.0, caracterizada por cuanto las publicaciones se
The society of knowledge is the result of the institutionalization and progress of science; and as such, it is now under construction (Lamo de Espinosa, 2009). Knowledge has always been a production factor. However, the current capacity to administrate, store and transmit large amounts of information at low cost is an essential element which characterizes the organizing and productive processes, and of course, the interactions in our society (Neubauer, 2012).

The public and private sectors commonly employ technological tools in their work, including social network applications such as Twitter, Facebook and Wikis. We have evolved from Web 1.0, characterized by publications which were unilateral, generating mainly static contents and 
realizaban de forma unilateral, generando contenidos principalmente estáticos y con serias dificultades de actualización; hacia la Web 2.0, cuya esencia se basa en la interacción y cooperación, ya que la creación y mantenimiento de contenidos en la web se sustenta en la colaboración de los usuarios. Ciertamente, la filosofía de la Web 2.0 se fundamenta en el protagonismo de los usuarios, quienes son los responsables de enlazar contenidos, descubrir, crear y modificar proyectos, enriqueciendo la red constantemente (Santoveña Casal, 2011).

Como lo señala Echeverría (2012), la emergencia de la sociedad-red o sociedad de la información está siendo lo suficientemente importante como para compararla con las grandes revoluciones tecnológicas de la historia. En efecto, la digitalización de la información y el empleo de Internet han facilitado el uso intensivo del conocimiento, transformando a este en un factor predominante de la creación de valor, tanto para las personas como para las organizaciones y para los países. Consecuentemente, la fuente de la ventaja competitiva reside en la capacidad para adquirir, transmitir y aplicar el conocimiento.

Lo anterior explica el creciente interés de las organizaciones en la búsqueda y aplicación de alternativas que potencien el desarrollo profesional de sus recursos humanos, porque mediante la gestión del conocimiento y de las comunidades de práctica los equipos pueden impactar sobre el desarrollo y mejora de las organizaciones (Gairín, 2012; Gairín, 2011a, 2011b; Rodríguez-Gómez, 2011).

De la vieja discusión acerca del origen del valor económico se asiste hoy, prácticamente, a un consenso en cuanto a que la combinación significativa entre trabajo productivo y aplicación intensiva del conocimiento representa el fundamento del valor económico y la productividad en la sociedad actual (Lakhani y Thusman, 2012; Esposto y Abbott, 2011; Castells, 2011, 2009).

El conocimiento proporciona capacidad de acción y decisión, otorgando poder a quienes lo poseen. Así, la sociedad del conocimiento será cada vez más competitiva, debido a que el conocimiento es ahora universalmente accesible. Peter Drucker, uno de los grandes pensadores del siglo XX, predijo hace dos décadas que en el futuro próximo no existirán países pobres, sino solo países incapaces de crear, adquirir y/o aplicar el conocimiento. $\mathrm{Al}$ respecto, Mellander et al. (2012) sostienen que no solo los ingresos de las personas y de las naciones, sino que su bienestar e incluso su felicidad dependerá with serious difficulties in updating, to Web 2.0, whose essence is based on interaction and cooperation, since creation and content in the web is based on the collaboration of the users. The philosophy of Web 2.0 is definitely founded in the active participation of the users, who are responsible for linking contents, discovering, creating and modifying projects, constantly enriching the network (Santoveña Casal, 2011).

As Echeverría (2012) indicated, the emergence of the network-society or society of information has become sufficiently important to compare it with the great technological revolutions of history. Digitalization of information and the use of the Internet have facilitated the intensive use of knowledge, transforming knowledge into a predominant factor in the creation of value for persons, organizations and countries. As a consequence, the source of competitive advantage lies in the capacity to acquire, transmit and apply knowledge. This explains the growing interest of organizations in the search for and application of alternatives which promote the professional development of their human resources, since through the management of knowledge and of the practicing community, the teams may have an impact on the development and improvement of organizations (Gairin, 2012; Gairín, 2011a, 2011b; Rodríguez-Gómez, 2011).

In the old discussion about the origin of economic value, today we are witnessing practically a consensus that the significant combination of productive labor and intensive application of knowledge is the basis of economic value and productivity in current society (Lakhani and Thusman, 2012; Esposto and Abbott, 2011; Castells, 2011, 2009). In this same vein, Hasan (2012) and earlier Salmi (2000) sustained that economic development, and thus the social development of countries, depends more on the accumulation of knowledge than on the accumulation of capital. Consequently, Acemoglu (2012) suggested that the basis of growth of nations is in the stock and flows of knowledge generated by a society.

Thus more and more societies require persons with continuous education, capacity of adaptation, good work practices and new models of interaction with organizations. Models of interaction, in which collaboration among the members of a team is vital to achieve a satisfactory level of 
cada vez más del conocimiento colectivo y del conocimiento individual.

En la misma línea, Hasan (2012) y previamente Salmi (2000) sostienen que el desarrollo económico $\mathrm{y}$, por ende, el desarrollo social de los países depende más de la acumulación de conocimiento que de la acumulación de capital. Consecuentemente, Acemoglu (2012) plantea que la base del crecimiento de las naciones está en el stock y los flujos de conocimiento generados por una sociedad.

Por lo tanto, las sociedades requieren, cada vez más, personas con educación continua, capacidad de adaptación, buenas prácticas de trabajo y nuevos modelos de interacción al interior de las organizaciones. Modelos de interacción en los que la colaboración entre los miembros de un equipo resultan ser vitales para lograr un nivel satisfactorio de gestión del conocimiento (Rodríguez-Gómez, 2011).

No es de sorprender, entonces, que en la actualidad el caudal de conocimientos necesario para poder funcionar con eficacia social sea muy elevado $\mathrm{y}$, por lo tanto, se requiera de una escolarización también larga. Por ejemplo, hasta $70 \%$ de jóvenes acuden en Japón o Estados Unidos a la educación terciaria. Incluso en un país emergente como lo es Chile, el $50 \%$ de los jóvenes ingresa a la educación terciaria (Rodríguez-Ponce, 2009a).

En virtud de lo anterior, la educación superior en la sociedad del conocimiento es equivalente a lo que era la enseñanza media en la sociedad industrial, siendo el doctorado el equivalente a lo que antes era la formación universitaria (Rodríguez-Ponce, 2009b).

De acuerdo con Castells (2011), el eje central de la sociedad actual se encuentra en la revolución experimentada por las tecnologías de la información, cuyo principal objetivo es la construcción de conocimiento en orden a generar ciclos permanentes de innovación y mejora en los distintos ámbitos de la sociedad.

Planteado en otros términos, en la sociedad de la información y del conocimiento el desarrollo integral está determinado por innovaciones tecnológicas y por la constitución de organizaciones que son exitosas en términos del aprendizaje. En la lógica de Smith (2012), las organizaciones exitosas utilizan el conocimiento que surge de sus prácticas para retroalimentarlas, modificarlas y perfilarlas en un horizonte de mejoramiento continuo.

Hoy la ciencia es la cultura dominante que incide en el quehacer integral de toda la humanidad (Lamo de Espinosa, 2009). Es de esta manera que la producción científica ha dado lugar a una nueva sociedad management of knowledge (Rodríguez-Gómez, 2011). It is therefore not surprising that the wealth of knowledge necessary to function with social efficacy is very high, and thus requires a long educational process. For example, $70 \%$ of young people in Japan and the USA have tertiary education. Even in emerging countries such as Chile, $50 \%$ of young adults enter tertiary education (Rodríguez-Ponce, 2009a). In view of the above, higher education in the society of knowledge is equivalent to what high school represented in the industrial society, and a doctorate is equivalent to what used to be university undergraduate studies (Rodríguez-Ponce, 2009b).

According to Castells (2011), the central axis of current society is the revolution experimented by information technologies, whose main objective is the construction of knowledge in order to generate permanent cycles of innovation and improvement in the different ambits of society. In other words, in the society of information and knowledge integral development is determined by technological innovations and by the constitution of organizations which are successful in terms of learning. In the logic of Smith (2012), successful organizations utilize the knowledge which stems from their practices to improve them with feedback, modify them and place them in a horizon of continuous improvement.

Today science is the dominant culture which affects the comprehensive task of all humanity (Lamo de Espinosa, 2009). It is the way in which scientific production, which has given rise to a new society and also to a new economy, called the economy of knowledge (Abrahams and Pogue, 2012; Castells, 2011, 2005). Universities constitute one of the institutions capable of fulfilling integrally the challenges inherent in the tertiary educational system. That is, universities are capable of creating advanced knowledge, contributing to the formation of advanced undergraduate and graduate human capital and contributing to social and territorial development. In order to do this, these institutions must perform their activities in a framework of quality.

The dominant literature in the area sustains that "quality in higher education is a dynamic polysemic concept with multiple levels which is related to the contextual elements of an educational 
y también a una nueva economía: la denominada economía del conocimiento (Abrahams y Pogue, 2012; Castells, 2011, 2005). Las universidades se constituyen en una de las instituciones capaces de cumplir integralmente los desafíos inherentes al sistema educativo terciario. Esto es, las universidades son capaces de crear conocimiento avanzado; contribuir a la formación de capital humano avanzado de pregrado y postgrado, y aportar al desarrollo social $\mathrm{y}$ territorial. Pero para tal efecto estas instituciones deben realizar su quehacer en un marco de calidad.

La literatura dominante sobre el tema sostiene que "calidad en educación superior es un concepto polisémico, de múltiples niveles, dinámico, que se relaciona con los elementos contextuales de un modelo educacional, con la misión y fines institucionales, y con estándares específicos dentro de un sistema, institución, programa o disciplina determinados" (Vlãsceanu, 2004).

No obstante lo anterior, definir qué es calidad para las entidades universitarias es una tarea difícil y no exenta de múltiples interpretaciones y perspectivas. En este contexto resulta pertinente exponer sintéticamente la aportación de Harvey y Green (1993), la que es aceptada crecientemente, ya que estos investigadores formulan cinco enfoques para entender y evaluar qué es calidad en la educación superior. Dichos enfoques son los siguientes (Pedraja, 2013):

La calidad como excepción, implica excelencia y como tal significa que una institución posee características superiores a las demás, es decir, dispone de rasgos propios no alcanzables por todas las entidades, sino que solo por las mejores organizaciones.

$>$ La calidad como perfección, se focaliza en el proceso y en el conjunto de especificaciones que deben lograrse para alcanzar la perfección. Desde este enfoque, la calidad se entiende como "cero defecto" y "hacer las cosas bien a la primera".

La calidad como logro de objetivos, referida al grado de cumplimiento de la misión, los propósitos y los objetivos institucionales, que han sido propuestos por la propia entidad. En cualquier caso se espera que los propósitos y objetivos se alineen con las necesidades o deseos de los usuarios hacia los cuales se dirigen los servicios académicos y los esfuerzos organizacionales complementarios. model, to institutional missions and frameworks, to specific standards within a determined system, institution, program or discipline (Vlãsceanu, 2004).

In spite of the above, defining what constitutes quality for a university is a difficult task, which is not exempt from multiple interpretations and perspectives. Thus it is pertinent to synthesize the contribution of Harvey and Green (1993), which is increasingly accepted; these researchers formulated five focuses to understand and evaluate what constitutes quality in higher education. Their focuses are the following (Pedraja, 2013):

D Quality as exception, which implies excellence, and as such signifies that an institution has characteristics which are superior to those of other institutions, has specific features which are not reachable by all entities, but only by the best ones.

$>$ Quality as perfection, which focuses on the process and on the set of specifications which must be achieved to reach perfection. Under this focus, quality is understood as "zero defects", and "doing things well the first time".

$>$ Quality as achieving objectives, referring to the degree of fulfillment of the mission, the institutional purposes and objectives which the institution itself has proposed. In any case, it is expected that the purposes and objectives are aligned with the needs or desires of the users to whom the academic services and complementary organizational efforts are directed.

Quality as monetary value or economic efficiency. Under this focus quality is evaluated in terms of the return on the investment. Thus it is understood that better quality is obtained when the same result may be obtained at a lower cost or a better result may be obtained for the same cost.

$>$ Quality as transformation, which is a classical notion of quality, evaluated in terms of the change from one state to another due to the execution of a process. Thus transformation is seen as a process of conversion of inputs into 


\section{$>\quad$ La calidad como valor por dinero o eficiencia} económica, desde este enfoque la calidad se evalúa en términos de retorno sobre la inversión. Por lo tanto, se entiende que se logra mayor calidad cuando el mismo resultado se puede obtener a un costo menor o un mejor resultado se puede lograr con el mismo costo.

> Calidad como transformación, es una noción clásica de calidad, la que se evalúa en términos de cambio de un estado a otro a partir de la ejecución de un proceso. Así, la transformación es un proceso de conversión de inputs en outputs, y en el caso específico de las instituciones de educación superior se refiere a los resultados de los procesos de formación de profesionales y postgraduados y a los procesos de investigación.

El trabajo mencionado precedentemente propone diferentes categorías para enfocar la calidad en las instituciones universitarias. Ciertamente, estas categorías no son excluyentes entre sí, por cuanto suponen perspectivas o enfoques complementarios para entender lo que es la calidad.

El acervo de conocimientos ha avanzado con múltiples aportes, hasta llegar a postular que la calidad de las instituciones de educación superior estriba en lograr consistencia interna y consistencia externa. Dicha propuesta fue elaborada por Van Damme et al. (2003), y las dimensiones básicas de consistencia interna y externa se pueden sintetizar de la siguiente manera:

$>$ Consistencia interna, medida por el grado de ajuste entre la misión y los propósitos de una institución de educación superior y los resultados reales que genera dicha organización.

$>$ Consistencia externa, medida por el grado de ajuste a las exigencias del medio externo, entendiéndose en esta dimensión al grupo de referencia institucional, disciplinario, profesional o tecnológico correspondiente.

El punto a destacar se sustenta en que una vez definidos los propósitos y fines institucionales, alcanzar calidad implica lograr coherencia entre dichos fines, los objetivos estratégicos y las actividades que la institución realiza efectivamente para su cumplimiento, considerando los medios que se emplean. Así, mediante una evaluación de estas acciones, se outputs, and in the specific case of institutions of higher education refers to the results of the processes of formation of professionals and graduate students and of the processes of research.

In this study Harvey and Green proposed different categories to focus on quality in university institutions. These categories are certainly not mutually exclusive, since they assume complementary perspectives or focuses to understand the concept of quality.

The pool of knowledge has advance with multiple contributions; it has even been proposed that the quality of higher education institutions is based on achieving internal and external consistency. This was the proposal of Van Damme et al. (2003); the basic dimensions of internal and external consistency may be synthesized as follows:

> Internal consistency, measured by the degree of fit between the mission and purposes of an institution of higher learning and the real results which this organization generates.

$>$ External consistency, measured by the degree of fit to the requirements of the external environment, understanding this dimension as the corresponding institutional, disciplinary, professional or technological reference group.

The point to be emphasized is that once the institutional mission and purposes are defined, achieving quality implies achieving coherence between these ends, the strategic objectives and activities which the institution actually performs to fulfill them, considering the means which it employs. Thus by evaluating the degree of advance in fulfilling the institutional purposes or objectives an internal perspective of quality may be obtained.

However, from the perspective of external consistency, higher education institutions must guarantee permanent improvement in their level of quality, which implies raising the self-defined standards to respond satisfactorily to the requirements of the scientific or disciplinary fields. As society progresses, the demands of quality continue to increase, and thus to achieve external consistency 
determinará el grado de avance en el cumplimiento de los propósitos u objetivos institucionales, dando una perspectiva interna de la calidad.

Sin embargo, desde la perspectiva de la consistencia externa, las instituciones de educación superior deben garantizar un mejoramiento permanente en sus niveles de calidad, lo que implica subir los estándares autodefinidos para responder satisfactoriamente a las exigencias del medio científico o disciplinario. En efecto, en la medida que la sociedad progresa las exigencias de calidad son cada vez mayores y, por lo tanto, para ser consistente externamente las instituciones están obligadas a velar y cumplir con los requerimientos del medio externo.

Por consiguiente, es posible plantear que:

La calidad posee múltiples dimensiones y se configura a partir del quehacer institucional.

$>$ En su evaluación se deben considerar diferentes niveles de análisis y una perspectiva de verificación permanente y sistemática, en tanto la calidad evoluciona y cambia con el tiempo.

> La consistencia interna implica desarrollar un quehacer institucional consistente con los propósitos, objetivos y promesas realizadas autónomamente por la propia entidad.

$>$ Cada entidad puede focalizar su quehacer en diferentes ámbitos, priorizando unos u otros de acuerdo con su proyecto institucional.

> La consistencia externa implica desarrollar un quehacer institucional consistente con los estándares exigidos por la comunidad científica o profesional.

En este contexto, instituciones universitarias deben asumir que realizar su labor con calidad es su desafío insoslayable en los tiempos actuales. Sin calidad, no hay universidad de verdad. Sin calidad, más temprano que tarde la institución quedará en evidencia ante sus alumnos, ante los empleadores, ante la sociedad. Por consiguiente, la definición de una clara misión institucional es una tarea esencial, pero dicha misión debe considerar inequívocamente las exigencias de la comunidad científica, de los pares, del medio profesional, porque en caso contrario una institución estará destinada a perder prestigio, a quedarse sin reputación y a ser postergada en la sociedad, arriesgando incluso su desaparición. institutions are obliged to monitor and fulfill the requirements of the external medium.

Thus we suggest that:

$>$ Quality has multiple dimensions and is configured by the activities of the institution.

$>$ Evaluation of quality must consider different levels of analysis and a perspective of permanent and systematic verification, since quality evolves and changes over time.

$>$ Internal consistency implies developing institutional activities consistent with the purposes, objectives and promises made by the institution itself.

$>$ Every entity may focus its activities in different areas, assigning priorities according to its institutional project.

$>$ External consistency implies developing institutional activities consistent with the standards required by the scientific or professional community.

In this context, university institutions must realize that performing their functions with quality is an unavoidable challenge in these times. Without quality it is not really a university. Without quality, sooner or later the deficiency of the institution will become evident to its students, its employers and the society. Thus a clear definition of the institutional mission is an essential task; however, this mission must consider correctly the exigencies of the scientific community, of its peers and the professional milieu, since otherwise an institution is destined to lose prestige, lose its reputation and be postponed by the society, even risking its disappearance. 


\section{Literatura Citada}

Abrahams, L.; Pogue, T.

2012. South Africa's national system of innovation and knowledge economy evolution: thinking about 'less favoured regions'. International Journal of Technological Learning, Innovation and Development, 5: 58-82.

Acemoglu, D.

2012. Introduction to economic growth. Journal of Economic Theory, 147: 545-550.

Allen, C.; Imrie, R. (Eds).

2010. The Knowledge Business: The Commodification of Urban and Housing Research. Burlington, VT: Ashgate Press.

Castells M.

2011. The Information Age Economy, Society, and Culture. The Power of Identity. 2nd Ed. United Kingdom: John Wiley \& Sons.

Castells, M.

2009. The Rise of the Network Society. United Kindom: John Wiley and Sons. $656 \mathrm{pp}$.

Castells M.

2005. Global Governance and Global Politics. PS: Political Science \& Politics, 38: 9-16.

Echeverría, J.

2012. Aprendizaje e innovación en la sociedad red. En: Gairín J. 2012. Gestión del conocimiento y desarrollo organizativo: formación y formación corporativa. Equipo de Desarrollo Organizacional (EDO) y Centro de Estudios Jurídicos y Formación Especializada (CEJFE). Barcelona. España.

Esposto, A.; Abbott, M.

2011. Human capital: A comparative study of the skill and knowledge intensity of work in Australia and New Zealand [online]. New Zealand Journal of Applied Business Research, http://search.informit.com.au/documentSumma ry; $\mathrm{dn}=448602711436309$. (Revisado en mayo de 2012).

Gairín, J.

2012. Gestión del conocimiento y desarrollo organizativo: formación y formación corporativa. Equipo de Desarrollo Organizacional (EDO) y Centro de Estudios Jurídicos y Formación Especializada (CEJFE). Barcelona. España.

Gairín, J.

2011a. El trabajo colaborativo en red: Actores y procesos en la creación y gestión del conocimiento colectivo. En Proyecto SEJ2007-67093/EDUC. Universidad Autónoma de Barcelona. España.

Gairín, J.

2011b. La colaboración entre profesionales, pp. 8-32. En: Gairín J. 2011. El trabajo colaborativo en red: Actores y procesos en la creación y gestión del conocimiento colectivo. Equipo de Desarrollo Organizacional (EDO). Barcelona. España.

Harvey, L.; Green, D.

1993. Defining quality, Assessment and evaluation in Higher education, Assessment \& Evaluation in Higher Education, 18: 9-34.

Hasan, S.

2012. Human development: perspectives, gaps and issues for MMCs. En Hasan, S. (Ed.) The muslim world in the 21st century. Space, power and human development (43-66). Dordrecht, Heidelberg, London, New York: Springer.

Lakhani, K.; Tushman, M.

2012. Open Innovation and Organizational Boundaries: The Impact of Task Decomposition and Knowledge Distribution on the Locus of Innovation. Harvard Business School Technology \& Operations Mgt. Unit Working Paper N ${ }^{\mathrm{o}} 12-57$; Harvard Business School Organizational Behavior Unit Working Paper $\mathrm{N}^{\circ}$ 12-057.

Lamo de Espinosa, E.

2009. Sociedad del conocimiento y cultura hipermoderna. Programa de Máster en Sociedad de la Información y del Conocimiento. Universidad Complutense de Madrid, España.

Mellander, C.; Florida, R.; Rentfrow, J.

2012. The creative class, post-industrialism and the happiness of nations. Cambridge Journal of Regions, Economy and Society, 5: 31-43.

Neubauer, D.

2012. Higher education regionalization in Asia Pacific: Implications for governance, citizenship and university transformation. Asian Education and Development Studies, 1: 11-17.

Pedraja Rejas, Liliana

2013. Proyecto Estratégico Institucional y la Calidad de las Universidades: Un Estudio desde Chile. Tesis en Preparación Doctorado en Ciencias de la Educación de la Pontificia Universidad Católica de Chile. Facultad de Educación. Pontificia Universidad Católica de Chile. Santiago, Chile. $391 \mathrm{p}$.

Rodríguez-Gómez, D.

2011. Comunidades de práctica. Una estrategia para el desarrollo efectivo de la creación y gestión del conocimiento en educación, pp. 33-45. En: Gairín J. 2011. El trabajo colaborativo en red: Actores y procesos en la creación y gestión del conocimiento colectivo. Equipo de Desarrollo Organizacional (EDO). Barcelona. España.

Rodríguez-Ponce, E.

2009a. The role of universities in the knowledge society and globalization: Evidence from Chile. Interciencia, 34 : 822-829.

Rodríguez-Ponce, E.

2009b. Las universidades en la sociedad del conocimiento, pp. 35-68. En Arata Andreani, A., \& Rodríguez Ponce, E. (Eds.) Desafíos y perspectivas de la dirección estratégica de las instituciones universitarias (35-68). Santiago: Ediciones CNA Chile.

Salmi, J.

2000. Tertiary Education in the Twenty-First Century: Challenges and Opportunities. Washington DC: The World Bank.

Santoveña Casal, S.

2011. La Sociedad del conocimiento desde la multiculturalidad popular y los entornos virtuales de aprendizaje. En: Foro de Educación, 13: 155-169.

Smith, P.

2012. The importance of organizational learning for organizational sustainability. Learning Organization, 19: 4-10. 
Van Damme, D.; Van der Hijden, P.; Campbell, C.

2003. International Quality Assurance and Recognition of Qualifications in Tertiary Education in Europe. OECD/ Norway Forum on Trade Educational Services. Managing the internationalisation of post-secondary education. Trondheim.
Vlãsceanu, L.; Grünberg, L.; Pârlea, D.

2004. Quality Assurance and Accreditation: A Glossary of Basic Terms and Definitions. In Conley Barrows, L. Papers on Higher Education. UNESCO. Bucarest. Rumania. 